\title{
City sewer collectors biocorrosion
}

\author{
Mariusz Książek ${ }^{1 *}$ \\ 1 Wrocław University of Technology, Institute of Building Engineering, Division of Building Materials, Timber and Monumental \\ Heritage Structures
}

Received 31 March 2014; accepted 23 July 2014

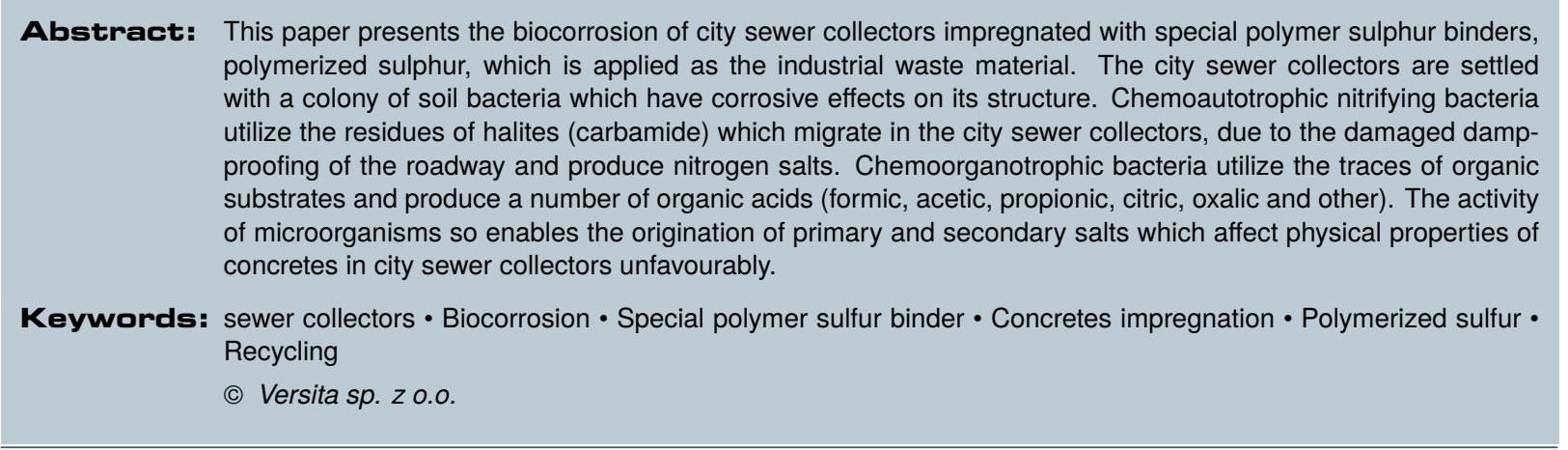

\section{Introduction}

Within the last fifty years, synthetic polymers have been employed to modify concretes (polymercement concretes, polymer impregnated concretes), and even to the production of concretes (resin concretes). The obvious aim was always "better concrete" [1-4, 15-17]. The general material concept of polymer concretes covers - from the technological point of view - the process during which the monomers, oligomers, pre-polymers or polymers are introduced into the concretes mix and, if chemically active, undergo to polymerization or polycondensation, usually initiated by catalysts [2-8, 24-28].

Polymer impregnated concretes (PIC), obtained by impregnation of the hardened concretes by monomer or

*E-mail: ksiazekmariusz@wp.pl pre-polymer and further polymerization of the modifier inside the concrete; these composites have very high mechanical strength (compressive strength above 140-150 $\mathrm{MPa}$ ) and good chemical resistance. The impregnation can be superficial (partial) or through [1-4, 9-15, 28-32].

The polymer can be introduced into concretes together with the mixing water (PCC), added to the concretes mix (PCC i PC), or, as the result of the specific technological operations, "forced" into the hardened concretes (PIC). The polymer concretes are also varied by the degree of substitution of the Portland cement: cementless in the case of $\mathrm{PC}$; in PMC the content of polymer does not exceed $4-7 \%$ of the cement mass; in PCC the content of polymer may reach up to $30-40 \%$ of the cement mass (however, most often not more than 5-20\%) [1-4, 3337, 39-42].

The Polymer Impregnated Concretes, PIC, are basically different from all other types of polymer concretes. In 
this case, the polymer is introduced into the hardened cement concretes. The result of this is an extraordinary increase of the tightness, manifesting itself by tenfold or even twentyfold downfall of the absorbability, from $5 \%$ for unmodified concrete to $0.30 \%-0.15 \%$ for impregnated concretes [2-4, 24-33].

The consequence of filling of the pores with polymer is also twofold to fourfold increase of compressive strength, twofold to threefold increase of tensile strength and fourfold decrease of the diffusion coefficient. PIC show more than three times lower creep. PIC have very high chemical resistance, significantly decreased penetration of chloride ions and improved frost resistance. Practically, the only disadvantage of PIC is the sudden mode of failure; modulus of elasticity can reach 40-50 GPa. This inconvenience can be eased, to some extent, by introduction of the suitable impregnating co-polymers [14, 15-23].

We can assume, therefore, that we have in disposal the perfect concretes, durable and with excellent technical features. The polymer impregnated concretes are known for 40-50 years, yet they are not widely implemented [24, 24-33].

The microbial corrosion represents an integral part of the concretes weathering in city sewer collectors impregnated with special polymer sulfur binder where polymerized sulfur applied as the industrial waste material. It becomes evident optically by patinas, efflorescences, pulverization and/or formation of fine cracks in the city sewer collectors concretes revetment. The presence of microbes on the concretes is generally limited above all, by the amount of nutrients, exposure to the cardinal points, texture, material composition and concretes moisture content [1-14, 33-40].

Experimental measurements evidenced convincingly that the main cause of the increased up to very high moisture content in the city sewer collectors impregnated special polymer sulfur binder - polymerized sulfur applied as the industrial waste material construction body (the arches up to $17 \%$, the piers up to $35 \%$ ) is the rain water seepage as a result of the deteriorated damp-proofing and, in the arch parts which are abutting on the piers, also of the diffusion by capillary elevation [2-4, 24-33].

A limited efficiency of the water vapour sorption is also observed which is due to the largely increased humidity of the environment over the sewers and which is accompanied by the water vapour diffusion into the city sewer collectors construction body. During the spring season, the water vapour condensation on cold surfaces of the concretes must also be added to the above causes. In addition, the city sewer collectors material composition is heterogeneous $[1-14,40-44]$.

\section{Description of investigations. Materials and methods}

The compositions of the special polymer sulfur binder (polymerized sulfur) applied as the industrial waste material: sulfur: $98,860 \%$ (S8), oil: $1,130 \%$, the ash: 0,010\%, producer "Siarkopol" Tarnobrzeg Sp. z o.o. The special sulfur binder applied as the industrial waste material view of the Figure 1 [33-40].

The results of the preliminary tests were analysed and the special polymer sulfur binder (polymerized sulfur) applied as the industrial waste material in the industries objects having the best properties among the tested composites was selected for further studies. The information relating preparations special polymer sulfur binder (polymerized sulfur) applied as the industrial waste material is given in Table 1. A view of the special sulfur binder applied as the industrial waste material presents in Figure 2 [33-40].

The Composition of cement concretes of city sewer collectors impregnated special polymer sulfur binder presents in Table 2. A view of the studied and estimated municipal collectors sewer special polymer sulfur binder - polymerized sulfur applied as the industrial waste material is presented in Figure 3. The view of studied concretes samples was showed on Figure 4 [33-40].

\section{Investigation results}

This diversity of used materials makes it difficult to select the uniform and comparable method in processing the results. This is also the reason why no significant dependence between the concrete $\mathrm{pH}$ value and the total amount of micro flora in the concretes was found out. Only in several places of the bridge the increased number of bacteria was corresponding to the lower $\mathrm{pH}$ value of the concretes and the other way round. Analogically no dependence between the water average content in the concretes and the total amount of microorganisms was found. High concentrations of bacteria, was found even in relatively low moisture content in the concretes in several samples, which can be explained by a massive contamination of the concretes surfaces with dust containing germs of microbes.

It was evident from the results that chemoorganotrophic microorganisms grew mostly up to the depth of 2-4 cm while their numbers decreased mostly at the depth of 7-9 $\mathrm{cm}$ considerably and that their growth and numbers were dependent on the oxygen access. However, there were several exceptions. The large amounts of germs were found also at the depth of 7-9 cm in the second and eighth piers and in the fourth, ninth and thirteenth arches. 
(a)
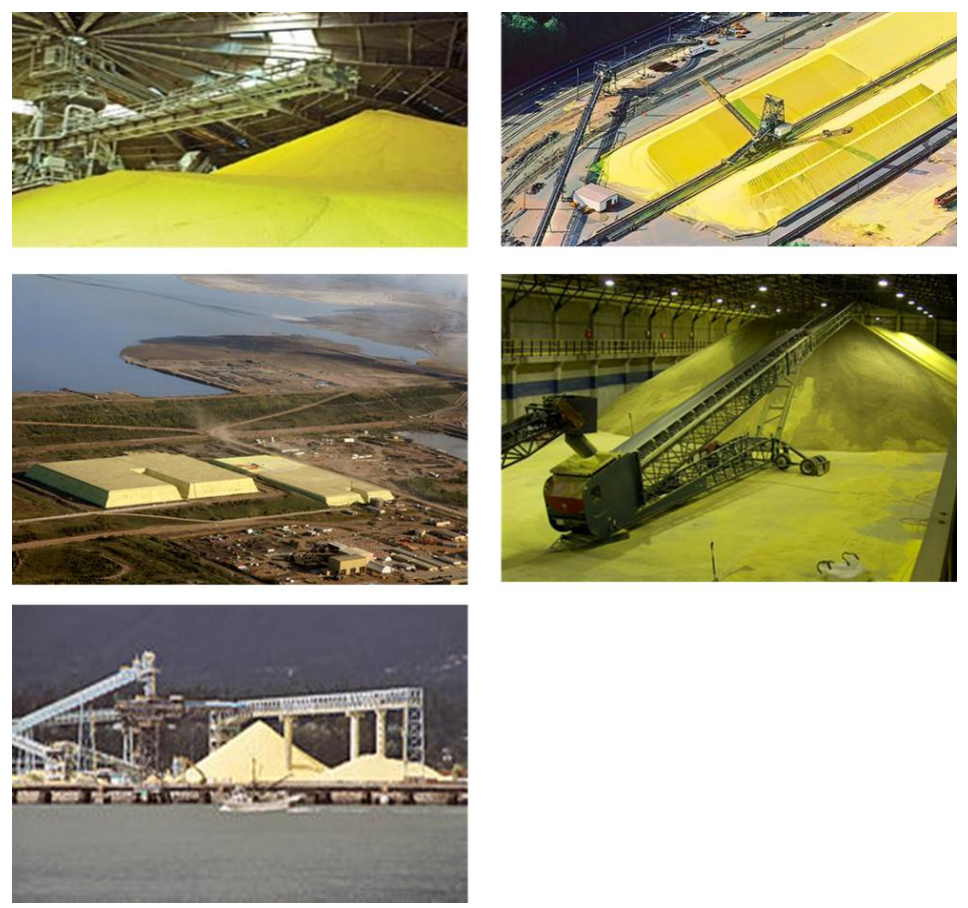

(b)
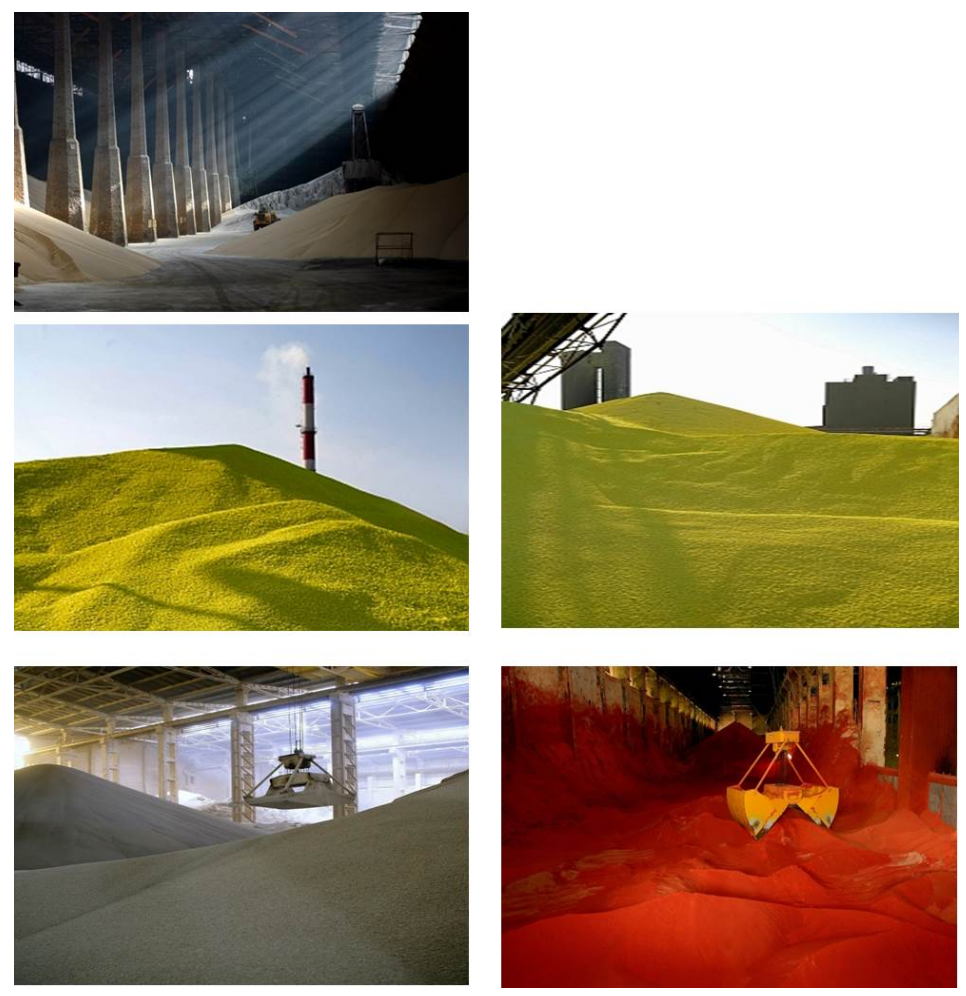

Figure 1. Special polymer sulfur binder applied as the industrial waste material, (a) in Europe, (b) in Poland [33-40]. 
Table 1. Information relating preparations special polymer sulfur binder - polymerized sulfur applied as the industrial waste material [33-40].

\begin{tabular}{|c|c|c|c|c|}
\hline Binder & $\begin{array}{l}\text { Temperature of } \\
\text { the polymerization composite } \\
{\left[{ }^{\circ} \mathrm{C}\right]}\end{array}$ & $\begin{array}{l}\text { Time of the } \\
\text { the polymerization composite } \\
{[\mathrm{min}]}\end{array}$ & $\begin{array}{c}\text { Time of }] \\
\text { coagulation of composite } \\
{[\mathrm{min}]}\end{array}$ & $\begin{array}{c}\text { The observation } \\
\text { comments }\end{array}$ \\
\hline polymerized sulphur & & & & \\
\hline $\begin{array}{l}\text { applied as the industrial } \\
\text { waste material }\end{array}$ & $150-155$ & $30-50$ & $10-20$ & - \\
\hline
\end{tabular}
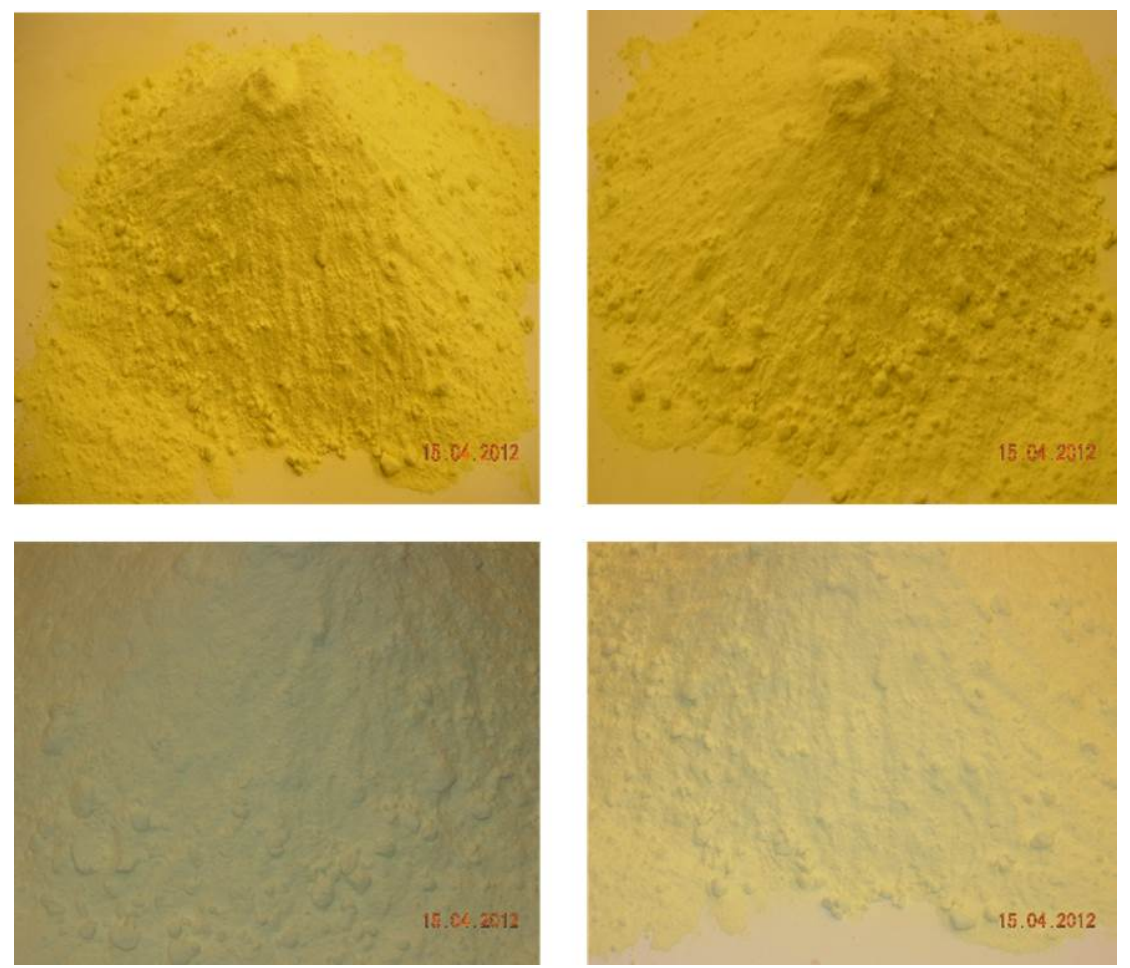

Figure 2. Special sulfur binder [33-40].

The main components of the biomass of black crusts were the micrococci together with the representatives of Bacillus genus. On the pulverized concretes and arkoses dark-pigmented micromycetes were found which belonged under the family Dematiaceae.

The massive occurrence of microorganisms similar to yeast was also remarkable; however, their cultivation was not successful. In the concrete layers near the surface the representatives of genera Bacillus, Micrococcus, Comamonas, Pseudomonas, Proteus and some forms of bacteria and fungi that have not yet been identified till now were found.

This was evident in all drill holes which affected this area (the environs of the drill holes above and below this level were always sterile). The microbic recesses found had no relation to the material composition of the piers (concretes and concretes impregnated with special polymer sulfur binder). The occurrence of the aerobic flora did not correlate with the moisture progressing as well. The objective explanation of this phenomenon is missing for the time being (cracks in the piers).

Aerobic nitrifying bacteria were found only in the superficial layers almost every time. However, as their numbers in the concretes increased in some cases, we speak of the bacteria with nitrifying properties. For example the heterotrophic nitrification 
(a)

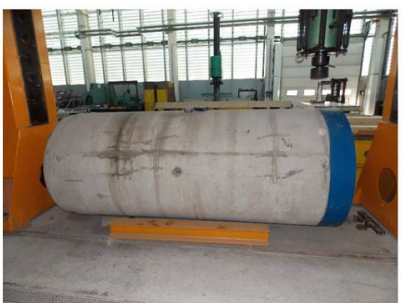

(d)

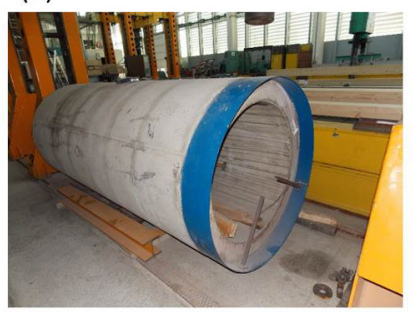

(g)

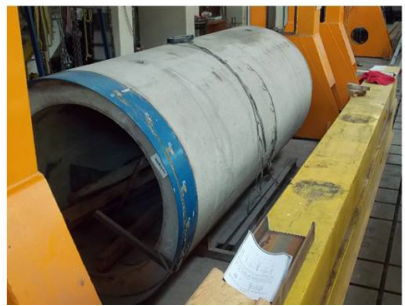

(b)

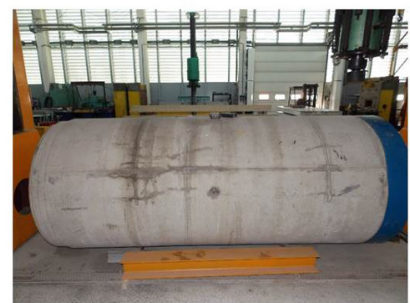

(e)

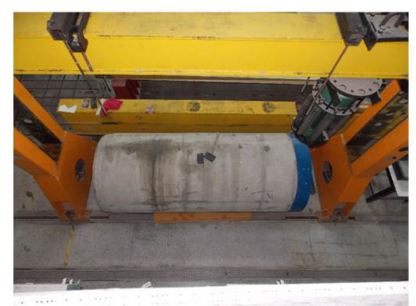

(c)

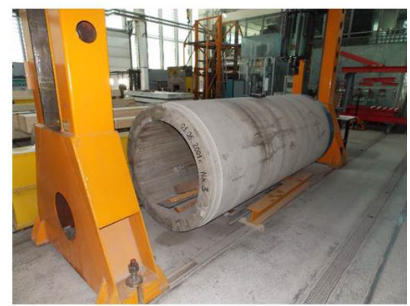

(f)

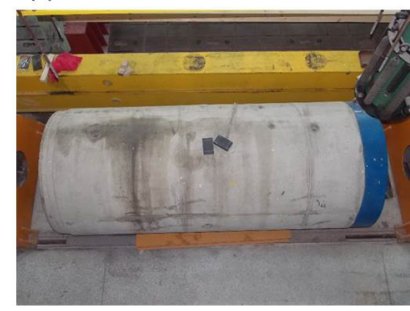

Figure 3. Studied municipal collectors sewers [33-40].

Table 2. The composition of cement concretes of city sewer collectors impregnated special polymer sulfur binder [3340].

\begin{tabular}{ll}
\hline $\begin{array}{l}\text { Cement concrete } \\
\text { constituent materials }\end{array}$ & $\begin{array}{l}\text { C30/37 } \\
\text { (B37) }\end{array}$ \\
\hline$\left[\mathrm{kg} / \mathrm{m}^{3}\right]$ & 760 \\
Aggregate 0-2 $\mathrm{mm}^{*}$ & 332 \\
Aggregate 2-8 $\mathrm{mm}^{*}$ & 674 \\
Aggregate 8-16 mm* & 372 \\
CEM I 32,5R & 212 \\
Water & \\
10\% Special polymer binder & \\
(polymerized sulfur) applied & 37.2 \\
as the industrial waste material \\
w/c
\end{tabular}

* Aggregate of the bad quality.

Aggregate comes from the processing of the rocks of sandstone. Aggregate makes up the waste from the processing of the rocks of sandstone. by chemoorganotrophic bacteria Pseudomonas and Alcaligenes.

The sulphur and anaerobic bacteria were present at greater depths (7-9 cm); in arches also at high concentrations (more than $1.10^{6}$ germs in one gram sample). The cultivatable forms of micromycetes appeared sporadically and were of no crucial importance in the concrete degradation process. Disregarding the immediate level of the concretes moisture content, most of germs were found in arches.

As the moisture content in the concretes increased mostly in the mentioned areas, we propose that just these places can be indicative for leakages. The different conditions affecting leakages into the city sewer collectors construction body can be demonstrated also by following results. Whereas the maximum microflora concentration at the feet of the city sewer collectors piers was found on the concrete surface in $55-60 \%$, the maximum of the microbial settlement in the city sewer collectors arches was concentrated at the depth of 7-9 cm in $60 \%$ samples, 

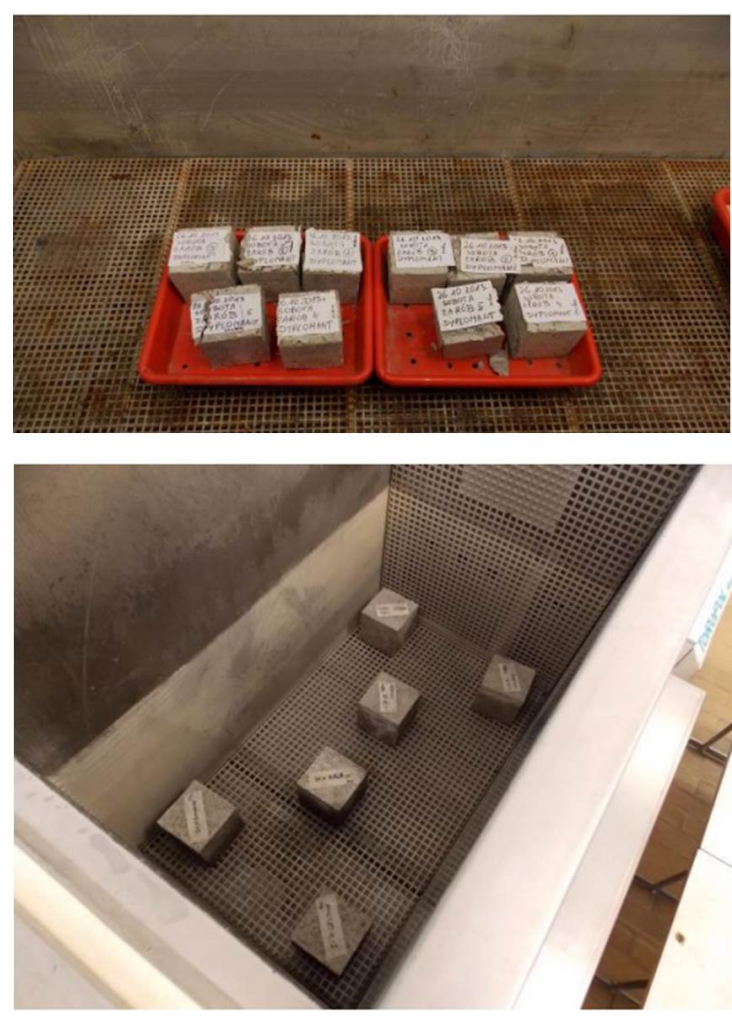

Figure 4. A view of studied concrete samples [33-40].

at the depth of $5-6 \mathrm{~cm}$ in $22 \%$ samples and on the surface in $22 \%$ samples. Therefore, in the city sewer collectors arches the prevailing source of moisture and nutrients exists inside the construction body of city sewer collectors. Also urea-based halites accelerated the development of urobacteria and nitrifying bacteria.

Urobacteria (the representatives of Bacillus, Sarcina, Micro coccus, Pseudomonas genera) decomposed the urea under the simultaneous formation of the ammonium carbonate, which was transformed finally into the nitric acid by nitrifying bacteria. This acid reacted with the concrete mineral components by which nitrates were produced. The $\mathrm{KNO}_{3}$ rephrase goes on participating in the formation of salt crusts and degrades the concretes surface structure considerably, $\mathrm{NO}_{3}$ salts, like $\mathrm{NO}_{2}$ salts produced by nitrifying bacteria, are prevailing on the surface and/or up to the depth of $5 \mathrm{~cm}$, Thanks to the migrating abilities of these salts the rise of nitrates was observed even at the depth of $9 \mathrm{~cm}$ in some cases.

As proved by chemical analyses, microorganisms produce aminoacids (asparagine, proline, leucine and others) and organic acids (citric, oxalacetic, oxalic, formic acids) in the concretes which weaken the concretes binder component under the simultaneous formation of salts (citrates, oxalacetates, oxalates, formates). Aminoacids and, above all, organic acids produce, together with metals contained in the concretes minerals, the specific complexes. This concerns especially citric acid $(\mathrm{KC}=$ $\left.\mathrm{OH} \cdot \mathrm{C} \cdot\left(\mathrm{CH}_{2}-\mathrm{CO}-\mathrm{OH}\right)_{2}-\mathrm{CO}-\mathrm{OH}\right)$ whose $\mathrm{OH}$ and $\mathrm{COOH}$ groups generate with $\mathrm{Fe}^{3+}$ and other metals the double complexes of type 1:1 $\mathrm{Fe}^{3+} \mathrm{KC}$, The conformation of complexes (chelates) affects the biodegradability of single molecules and the liberation of ions of single metals into the condensate on the concretes surfaces in city sewer collectors [32-38].

Also microbic aminoacids (Pseudomonas putida) are capable to solubilize $\mathrm{Ca}, \mathrm{Zn}, \mathrm{Ni}$ and $\mathrm{Al}$ ions from the corresponding sulphates and oxides in similar way. $\mathrm{Mn}^{3+}$ and $\mathrm{Mn}^{4+}$ are also quickly liberated from the concretes by the specific microbic ferments. During all these processes the degradation of the crystal lattice of clay minerals occurs, which results in the deep deterioration of the concretes structure that is also reflected in the accelerated transport of water and water vapour into the anorganic building materials. During last ten years, 24 minerals were identified gradually in the form of efflorescences and in the porous system of the studied concretes ashlars by the $X$-ray and microanalyses.

Not only pressures of microbic salts in the concretes, which accelerate then the formation of micro cracks and largely increase the instability of the concretes surface layers, but also the migration of "brines" in the rock porous system, are of the crucial hydrating and recrystallizing importance in the concretes degradation process. This migration may result in the formation of minerals in the porous system, or may reach the surface and cause the origination of minerals of the surface crusts - the efflorescences. In the degraded concretes of city sewer collectors there are mostly present various forms of bassanite $\left(\mathrm{CaSO}_{4} \cdot \frac{1}{2} \mathrm{H}_{2} \mathrm{O}\right)$, gypsum $\left(\mathrm{CaSO}_{4} \cdot 2 \mathrm{H}_{2} \mathrm{O}\right)$, thenardite $\left(\mathrm{Na}_{2} \mathrm{SO}_{4}\right)$, mirabilite $\left(\mathrm{Na}_{2} \mathrm{SO}_{4} \cdot \mathrm{H}_{2} \mathrm{O}\right)$ and mixed $\mathrm{Na}, \mathrm{K}$ - alums, thermonatrite $\left(\mathrm{Na}_{2} \mathrm{CO}_{3} \cdot \mathrm{H}_{2} \mathrm{O}\right)$, nitrokalite $\left(\mathrm{KNO}_{3}\right)$, nitronatrite $\left(\mathrm{NaNO}_{3}\right)$, halite $(\mathrm{NaCl})$ [33-40].

Despite the fact that it cannot be expected that the newly formed minerals were produced by the activities of microorganisms in all cases, their effect cannot be underestimated at all. The minerals that participate in the concretes destruction can have their source in the city sewer collectors structure core and can reach the surface by the migration by means of "brines", can "be leached, concentrated or be depleted during such transport", and other "forms of salt solutions" and, thus, also communities of salts can be produced under the influence of microorganisms. 


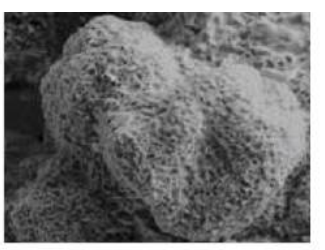

1

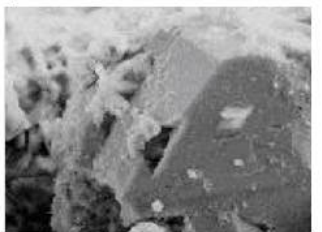

5

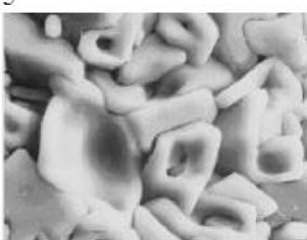

9

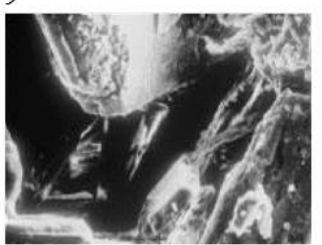

13

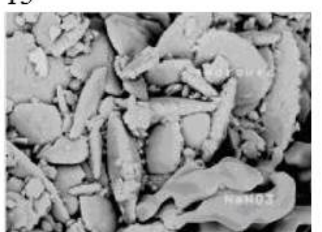

17

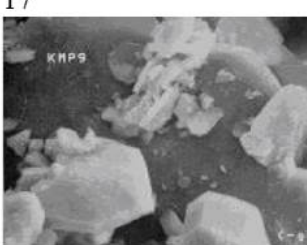

21

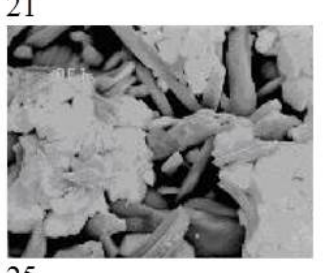

25

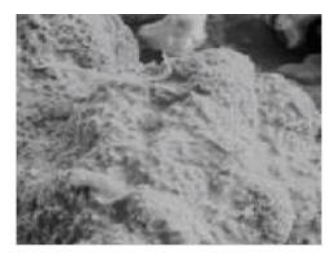
2

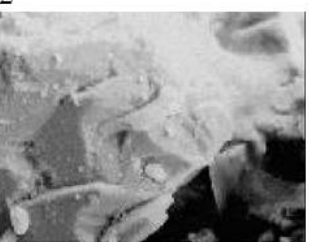

6
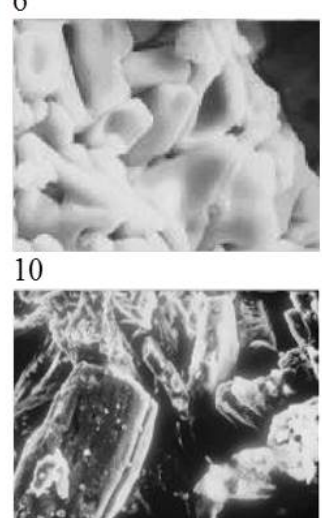

14

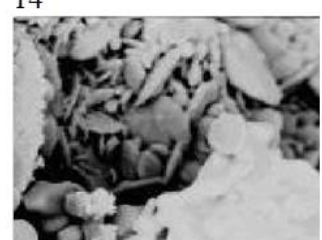

18
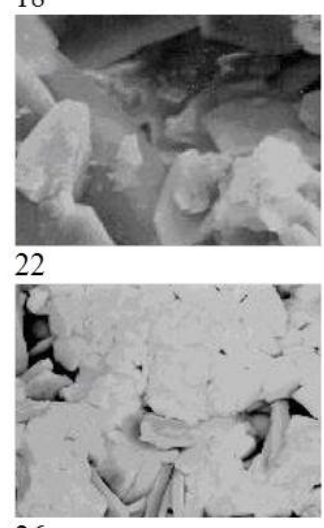

26

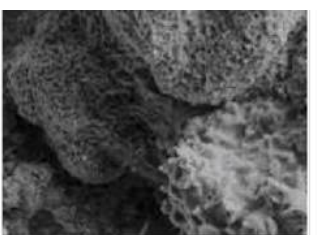

3
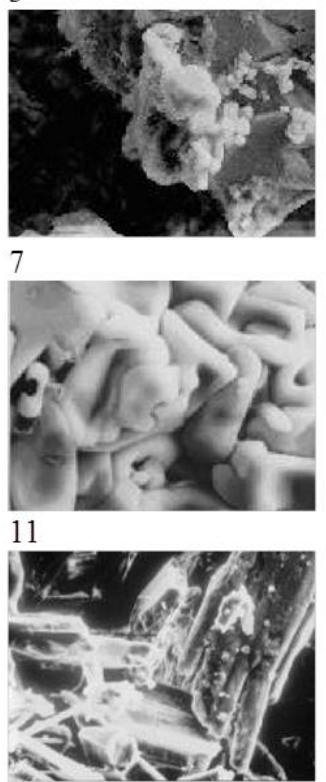

15

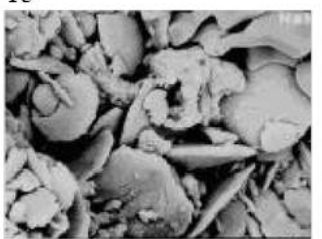

19

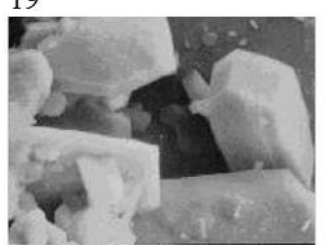

23

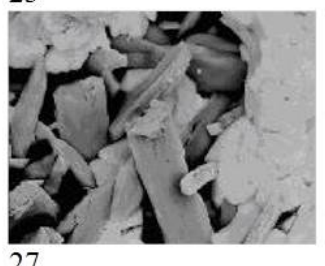

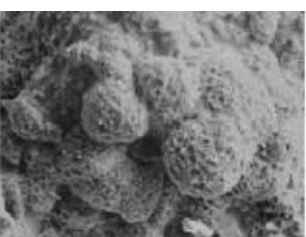

4

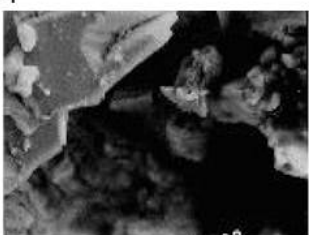

8

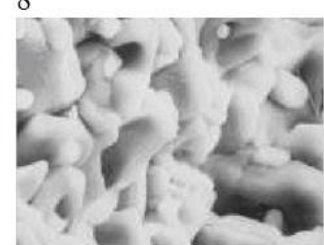

12

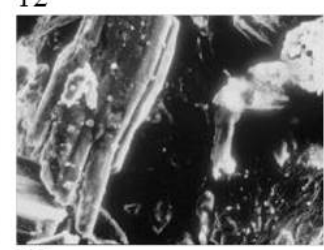

16

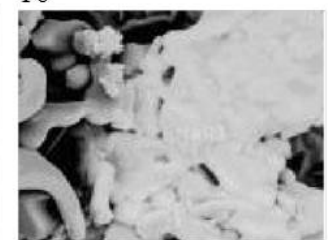

20

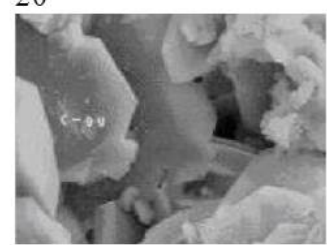

24

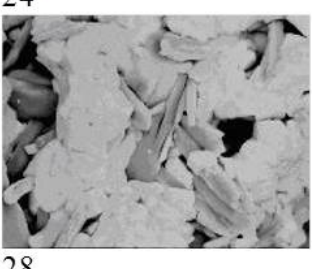

Figure 5. A view of the crystals of minerals on the surface. 1-4: K-Na chlorides - The general view of a salt rose blooming on the surface of the concretes. 5-8: Crystals of chlorides - The gradually growing quartz crystal. 9-12: A detail of mixed salts of $\mathrm{K}$ and Na chlorides. 13-16: $\mathrm{Na}$ and $\mathrm{K}$ nitrosalts, tablet-like crystals. 17-20: Crystals of the tack-like gypsum and slightly etched halite and of nitronatrite. 21-24: Perfectly bounded crystals of the gypsum. 25-28: The mix of crystals of water-soluble sulphates and of halite [33-35]. 
A view of the crystals of minerals on the surface presents in Figure 5. The resulting mineral associations assume then the looks of mineral coats (Figure 51-4), isolated crystals on the surface of the primary minerals of concretes (Figure 5(5-8)) or mixed salts of the same kind with striking features of corrosion and regeneration (Figure 5(9-12)). Nor associations of stable and unstable mineral forms either are the exception as it can be observed from the example of the tack-like gypsum, slightly etched halite and nitronatrite (Figure 5(13-16)). In the porous system there can appear also the mineral shapes that are striking from the morphology viewpoint (Figure 5(17-20)). Some associations of water-soluble salts are also interesting, be there concerned the tabletlike crystals (Figure 5(21-24)) or the thin-needle crystals of halotrichite or pickeringite (Figure 5(25-28)) [32-35].

\section{Conclusion}

It is apparent that the surface treatment of concrete specimens with special polymer sulfur binder polymerized sulfur applied as the industrial waste material, reduces water, aggressive liquid and sewers penetration.

Results of chemical and microbiological analyses of the sand concretes evidence the pervasive growth of the content of nitrates and nitrites as a result of the decomposition of urea-based halites. At the same time the numbers of microorganisms which produce nitrates, sulphates, citrates, salicylates, oxalacetates, formates, oxalates and other substances, which clog or open the concretes pores and contribute to the transport as well as transformation of minerals contained in the concretes, increase on the concretes considerably.

Salts, owing to their hygroscopic qualities, receive or liberate water in compliance with changes of the equilibrium of internal and external environments. In this way hydration and crystallization pressures arise, while hydration pressures are more dangerous than the crystallization ones, as they are variable in dependence on the climate fluctuations as in the course of a year, as also often during one day.

Hydration and recrystallization pressures of microbic salts in the concretes accelerate the formation of micro cracks in the concretes and increase the instability of surface layers considerably. Results of mineralogical analyses evidenced conductively the occurrence of crystals of chlorides, nitrates, water-soluble sulphates and urea.

\section{References}

[1] Btaszczynski T.Z., The influence of crude oil products on RC structure destruction. Civil Engineering and Management, 17(1), 2011, 146-156, DOI: 10.3846/13923730.2011.561522

[2] Czarnecki L., Garbacz A., Evaluation of polymer coating-crack-bridging ability. International Colloquium "Industrial Floors" 95, Esslingen, 1995

[3] Czarnecki L., Emmons P.H., Repair and protection of concrete structures (in Polish), Wydawnictwo Polski Cement, Kraków, 2002

[4] Czarnecki L., Polymer Concretes, Cement-WapnoBeton, Vol. XV/LXXVII, 2, 2010, 63-85

[5] Gorzelańczyk T., Hota J., Sadowski Ł., Schabowicz $K$., Methodology of nondestructive identification of defective concrete zones in unilaterally accessible massive members. Civil Engineering and Management, 19(6), 2013, 775-786, DOI: dx.doi.org/10.3846/13923730.2013.812577

[6] Gorzelańczyk T., Hota J., Pore structure of self-compacting concretes made using different superplasticizers. Archives of Civil and Mechanical Engineering, 11(3), 2011, 611-621

[7] Hota J., Matkowski Z., Schabowicz K., Sikora J., Nita K., Wójtowicz S., Identification of moisture content in brick walls by means of impedance tomography. Compel, 31(6), 2012, 17741792, http://www.emeraldinsight.com/journals.htm? articleid $=17063665$

[8] Schabowicz K., Hota J., Nondestructive elastic-wave tests of foundation slab in office building. Materials Transactions, 2012, Vol. 53, No. 2, pp. 296-302. http: //www.jim.or.jp/journal/e/53/02/296.html

[9] Hota J., Sadowski Ł., Schabowicz K., Nondestructive identification of delaminations in concrete floor toppings with acoustic methods. Automation in Construction, 20(7), 2011, 799-807, http://dx.doi.org/ 10.1016/j.autcon.2011.02.002

[10] Hota J., Schabowicz K., State-of-the-art nondestructive methods for diagnostic testing of building structures - anticipated development trends. Archives of Civil and Mechanical Engineering, 10(3), 2010, 5-18, http://www.acme.pwr.wroc.pl/repository/ 282/online.pdf

[11] Hota J. Książek M., Research on usability of sulphur polymer composite for corrosion protection of reinforcing steel in concrete. Archives of Civil and Mechanical Engineering, 9(1), 2009, 47-59, http: //www.acme.pwr.wroc.pl/repository/230/online.pdf 
[12] Polakowski K., Sikora J., Filipowicz S., Hota J., Schabowicz K., Wójtowicz S., Biernat K., Wall humidification imaging by ultrasonic tomography. Przeglạd Elektrotechniczny, 5, 2007, 116-121

[13] Hota J., Schabowicz K., Methodology of neural identification of strength of concrete. $\mathrm{ACl}$ Materials Journal, 102(6), 2005, 459-464

[14] Hota J., Schabowicz K., New technique of nondestructive assessment of concrete strength using artificial intelligence. NDT and E International, 38(4), 2005, 251-259

[15] Jasieńko J., Nowak T., Bednarz Ł., Baroque structural ceiling over the Leopoldinum Auditorium in Wroctaw University. International Journal of Architectural Heritage, 8(2), 2014, 269-289, http://dx.doi.org/10. 1080/15583058.2012.692848

[16] Nowak T., Jasieńko J., Czepiżak D., Experimental tests and numerical analysis of historic bent timber elements reinforced with CFRP strips. Construction and Building Materials, 40, 2013, 197-206, http: //dx.doi.org/10.1016/j.conbuildmat.2012.09.106

[17] Bednarz Ł., Górski A., Jasieńko J., Rusiński E., Simulations and analyses of arched brick structures. Automation in Construction, 20(7), 2011, 741-754, http://dx.doi.org/10.1016/j.autcon.2011.01.005

[18] Jankowski L., Jasieńko J., Nowak T., Experimental assessment of CFRP reinforced wooden beams by 4-point bending tests and photoelastic coating technique. Materials and Structures, 43(1/2), 2010, 141-150, http://dx.doi.org/10.1617/ s11527-009-9476-0

[19] Jasieńko J., Nowak T., Bednarz Ł., Wroctaw University's Leopoldinum Auditorium - tests of its ceiling and a conservation and strengthening concept. Advanced Materials Research, 133/134, 2010, 265270

[20] Nowak T. Jankowski L., Jasieńko J., Application of photoelastic coating technique in tests of solid wooden beams reinforced with CFRP strips. Archives of Civil and Mechanical Engineering, 10(2), 2010, 53-66, http://www.acme.pwr.wroc.pl/repository/271/ online.pdf

[21] Jasieńko J. Bednarz Ł., Nowak T., The effectiveness of strengthening historic brick vaults by contemporary methods. Proceedings of the International Conference on Protection of Historical Buildings, Rome, Italy, 2124 June 2009, Vol. 2, 1299-1304

[22] Jasieńko J., Nowak T., Bednarz Ł., Reinforcement of bent timber beams in historic buildings. Proceedings of the International Conference on Protection of Historical Buildings, Rome, Italy, 21-24 June 2009, Vol. 1, 325-330
[23] Jasieńko J., Stawiski B., Analysis of cracking plane geometry in old sandstone columns. Materials and Structures, 34(238), 2001, 248-252

[24] Bywalski Cz., Kamiński M., Rheological strains in concrete modified with steel fibre reinforcement. Journal of Civil Engineering and Management, 19(5), 2013, 656-664, http://dx.doi.org/10.3846/13923730. 2013.803497

[25] Kamiński M., Kusa E., Demski D., Time-dependent behaviour of CFRP-strengthened reinforced concrete beams. Concrete solutions. Proceedings of Concrete Solutions, 4th International Conference on Concrete Repair, Dresden, Germany, 26-28 September 2011, 2012, 697-704

[26] Pawlak W., Kamiński M., Cracking of reinforced concrete beams under torsion - theory and experimental research. Archives of Civil and Mechanical Engineering, 12(3), 2012, 368-375, http://dx.doi.org/10.1016/j.acme.2012.05.003

[27] Trapko T., Kamiński M., Musiał M., Investigations on rheological strains of compressed concrete elements strengthened with external composite reinforcement CFRP. Composites. Part B, Engineering, 43(3), 2012, 1417-1424, http://dx.doi.org/10.1016/j.compositesb. 2011.09.009

[28] Bywalski Cz., Kamiński M., Estimation of the bending stiffness of rectangular reinforced concrete beams made of steel fibre reinforced concrete. Archives of Civil and Mechanical Engineering, 11(3), 2011, 553-571, http://www.acme.pwr.wroc.pl/ repository/334/online.pdf

[29] Kamiński M., Pawlak W., Load capacity and stiffness of angular cross section reinforced concrete beams under torsion. Archives of Civil and Mechanical Engineering, 11(4), 2011, 885-903, http://www.acme. pwr.wroc.pl/repository/356/online.pdf

[30] Kamiński M., Musiat M., Ubysz A., Eigenfrequencies of the reinforced concrete beams - methods of calculations. Journal of Civil Engineering and Management, 17(2), 2011, 278-283, http://www.tandfonline.com/doi/abs/10.3846/ 13923730.2011.576812

[31] Kmiecik P., Kamiński M., Modelling of reinforced concrete structures and composite structures with concrete strength degradation taken into consideration. Archives of Civil and Mechanical Engineering, 11(3), 2011, 623-636, http: //www.acme.pwr.wroc.pl/repository/338/online.pdf

[32] Klakočar-Ciepacz M., Książek M., Investigation of the intensity of corrosion processes influence by tensile stress for reinforcing steel covered with sulphuric coating. Chemicals in sustainable 
agriculture, Jesenik, 2003, 761-765

[33] Książek M., Biological corrosion of the sandstone of the quay of the river of Odra in Wroctaw. Engineering Failure Analysis, 44, 2014, 338-344, DOI: 10.1016/j.engfailanal.2014.05.003

[34] Książek M., The biocorrosion of city sewer collector impregnated special polymer sulfur binder - polymerized sulfur applied as the industrial waste material. Construction and Building Materials, 2014, DOI: 10.1016/j.conbuildmat.2014.06.077

[35] Książek M., The influence of penetrating special polymer sulfur binder - polymerized sulfur applied as the industrial waste material on concrete watertightness. Composites Part B, Engineering, 62(62C), 2014, 137-142. DOI: 10.1016/j.compositesb.2014.02.027

[36] Książek M., The evaluate tendencies of corrosion process for reinforcing steel when covered with special polymer sulfur coating. Engineering Failure Analysis, 39, 2014, 1-11, DOI: dx.doi.org/10.1016/j.engfailanal.2014.01.005

[37] Książek M., The experimental investigations of propriety and applies in the building special coating - sulphur polymer composite as the industrial waste material. Composites Part B, Engineering, 58(58C), 2014, 378-385, DOI: 10.1016/j.compositesb.2013.10.087

[38] Książek M., The intensity of corrosion processes influenced by tensile stress for reinforcing steel covered with sulphur polymer composite applied as industrial waste material. Composites. Part B, Engineering, 45(1), 2013, 1126-1132, DOI: dx.doi.org/10.1016/j.compositesb.2012.04.072

[39] Książek M., Experimental research on the surface protection of concrete by polymer sulfur composite. Magazine of Concrete Research, 64(10), 2012, 945955, DOI: dx.doi.org/10.1680/macr.11.00142

[40] Książek M., The experimental and innovative research on usability of sulphur polymer composite for corrosion protection of reinforcing steel and concrete. Composites. Part B, Engineering, 42(5), 2011, 1084-1096. DOI: dx.doi.org/10.1016/j.compositesb.2011.03.022

[41] Łowińska-Kluge A., Błaszczyński T., The influence of internal corrosion on the durability of concrete. Archives of Civil and Mechanical Engineering, 12(2), 2012, 219-227, DOI: 10.1016/j.acme.2012.03.002

[42] Maksymowicz M., Cruz P.J.S., Bień J., Load capacity of damaged RC slab spans of railway-bridges. Archives of Civil and Mechanical Engineering, 11(4), 2011, 963-978

[43] Thomas C., Cimentada A., Polanco J. A., Setien J., Mendez D., Rico J., Influence of recycled aggregates containing sulphur on properties of recycled aggregate mortar and concrete. Composites Part B-Engineering, 45(1), 2013, 474-485, DOI: 10.1016/j.compositesb.2012.05.019

[44] Zhang P. H., He J. J., Zhang D. D. Wu L. M., A fault diagnosis method for substation grounding grid based on the square-wave frequency domain model, Metrology and Measurement System, 19(1), 2012, 63-71, DOI: 10.2478/v10178-012-0005-z 